In cooperation with the U.S. Environmental Protection Agency

\title{
Internet-Based Interface for STRMDEPL08
}

Open-File Report 2010-1247 



\section{Internet-Based Interface for STRMDEPL08}

By Howard W. Reeves and A. Jeremiah Asher

In cooperation with the U.S. Environmental Protection Agency

Open-File Report 2010-1247

U.S. Department of the Interior

U.S. Geological Survey 


\title{
U.S. Department of the Interior \\ KEN SALAZAR, Secretary \\ U.S. Geological Survey \\ Marcia K. McNutt, Director
}

\section{U.S. Geological Survey, Reston, Virginia: 2010}

\author{
For more information on the USGS — the Federal source for science about the Earth, its natural and living resources, \\ natural hazards, and the environment, visit http://www.usgs.gov or call 1-888-ASK-USGS \\ For an overview of USGS information products, including maps, imagery, and publications, \\ visit http://www.usgs.gov/pubprod \\ To order this and other USGS information products, visit http://store.usgs.gov
}

\begin{abstract}
Any use of trade, product, or firm names is for descriptive purposes only and does not imply endorsement by the U.S. Government.

Although this report is in the public domain, permission must be secured from the individual copyright owners to reproduce any copyrighted materials contained within this report.
\end{abstract}

Suggested citation:

Reeves, H.W., and Asher, A.J., 2010, Internet-based interface for STRMDEPL08: U.S. Geological Survey Open-File Report 2010-1247, 17 p. 


\section{Contents}

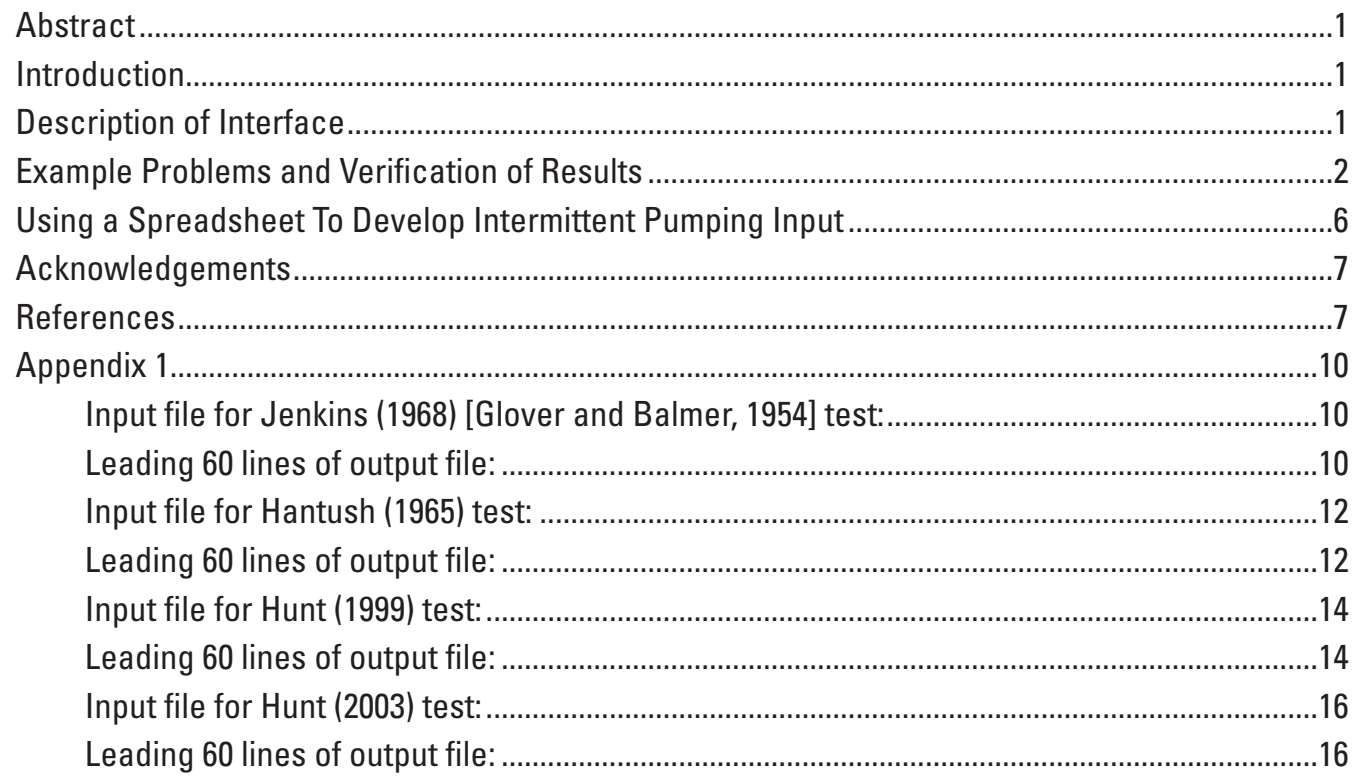

\section{Figures}

1-4. Graphs showing:

1. Comparison of results determined by the internet-based version and the Fortran version of STRMDEPL08 for the Jenkins (1968) (Glover and Balmer, 1954) analytical solution

2. Comparison of results determined by the internet-based version and the Fortran version of STRMDEPL08 for the Hantush (1965) analytical solution.

3. Comparison of results determined by the internet-based version and the Fortran version of STRMDEPL08 for the Hunt (1999) analytical solution.

4. Comparison of results determined by the internet-based version and the Fortran version of STRMDEPL08 for the Hunt (2003) analytical solution.

5. Example spreadsheet that may be used to help generate intermittent pumping input information for STRMDEPL08. 


\section{Conversion Factors}

\section{Inch/Pound to SI}

\begin{tabular}{|c|c|c|}
\hline Multiply & By & To obtain \\
\hline \multicolumn{3}{|c|}{ Length } \\
\hline foot $(\mathrm{ft})$ & 0.3048 & meter $(\mathrm{m})$ \\
\hline \multicolumn{3}{|c|}{ Area } \\
\hline square foot $\left(\mathrm{ft}^{2}\right)$ & 0.09290 & square meter $\left(\mathrm{m}^{2}\right)$ \\
\hline \multicolumn{3}{|c|}{ Volume } \\
\hline gallon (gal) & 3.785 & liter (L) \\
\hline gallon (gal) & 0.003785 & cubic meter $\left(\mathrm{m}^{3}\right)$ \\
\hline \multicolumn{3}{|c|}{ Flow rate } \\
\hline foot per day (ft/d) & 0.3048 & meter per day $(\mathrm{m} / \mathrm{d})$ \\
\hline cubic foot per second $\left(\mathrm{ft}^{3} / \mathrm{s}\right)$ & 0.02832 & cubic meter per second $\left(\mathrm{m}^{3} / \mathrm{s}\right)$ \\
\hline gallon per minute (gal/min) & 0.06309 & liter per second $(\mathrm{L} / \mathrm{s})$ \\
\hline \multicolumn{3}{|c|}{ Mass } \\
\hline pound, avoirdupois (lb) & 0.4536 & kilogram (kg) \\
\hline \multicolumn{3}{|c|}{ Hydraulic conductivity } \\
\hline foot per day $(\mathrm{ft} / \mathrm{d})$ & 0.3048 & meter per day $(\mathrm{m} / \mathrm{d})$ \\
\hline \multicolumn{3}{|c|}{ Transmissivity* } \\
\hline foot squared per day $\left(\mathrm{ft}^{2} / \mathrm{d}\right)$ & 0.09290 & meter squared per day $\left(\mathrm{m}^{2} / \mathrm{d}\right)$ \\
\hline
\end{tabular}

*Transmissivity: The standard unit for transmissivity is cubic foot per day per square foot times foot of aquifer thickness [(ft $\left.\left.\mathrm{ft}^{3} / \mathrm{d}\right) / \mathrm{ft}^{2}\right] \mathrm{ft}$. In this report, the mathematically reduced form, foot squared per day $\left(\mathrm{ft}^{2} / \mathrm{d}\right)$, is used for convenience. 


\title{
Internet-Based Interface for STRMDEPL08
}

\author{
Howard W. Reeves ${ }^{1}$ and A. Jeremiah Asher ${ }^{2}$
}

\section{Abstract}

The core of the computer program STRMDEPL08 that estimates streamflow depletion by a pumping well with one of four analytical solutions was re-written in the Javascript software language and made available through an internetbased interface (web page). In the internet-based interface, the user enters data for one of the four analytical solutions, Glover and Balmer (1954), Hantush (1965), Hunt (1999), and Hunt (2003), and the solution is run for constant pumping for a desired number of simulation days. Results are returned in tabular form to the user. For intermittent pumping, the interface allows the user to request that the header information for an input file for the stand-alone executable STRMDEPL08 be created. The user would add the pumping information to this header information and run the STRMDEPL08 executable that is available for download through the U.S. Geological Survey. Results for the internet-based and stand-alone versions of STRMDEPL08 are shown to match.

\section{Introduction}

The STRMDEPL computer code (Barlow, 2000) implements two analytical solutions for streamflow depletion by a well and uses superposition to allow for varying pumping rates. The first solution is for a system with a stream that fully penetrates the aquifer with no streambed resistance between the stream and the aquifer (Glover and Balmer, 1954; Jenkins, 1968). The second solution is for a system with a stream that fully penetrates the aquifer with streambed resistance between the stream and the aquifer (Hantush, 1965). The code was modified by the addition of two more analytical solutions and the ability to evaluate time intervals other than one day. The new solutions are for a system with a partially penetrating stream with streambed resistance (Hunt, 1999), and for system with a stream in an aquitard with pumping from an underlying leaky aquifer (Hunt, 2003). The modified code is STRMDEPL08 (Reeves, 2008).

${ }^{1}$ U.S. Geological Survey

${ }^{2}$ Michigan State University, Institute for Water Research
Both STRMDEPL and STRMDEPL08 are written in Fortran and require an ASCII text input file. Use of the input file can be confusing to users because of the units used in the programs and the use of diffusivity (transmissivity/storativity). In addition, STRMDEPL08 was written to allow for use of older STRMDEPL input files which also can be confusing because input variables have different meanings depending on the analytical solution selected by the user. To resolve these issues and to make access easier, a simple interface to STRMDEPL08 was developed to evaluate the analytical solutions on the internet. The internet-based program was developed by rewriting the core functions of STRMDEPL08 in Javascript which is a language that runs on the user's computer through web pages (client-side processing). The only major feature of STRMDEPL08 that was not incorporated into the internet version is the ability to evaluate time-varying pumping rates through superposition. This feature was not included because web-based applications with Javascript require fairly fast computations and the use of superposition for time-varying pumping rates can be computationally intensive. Users wanting to evaluate time-varying pumping rates can use the stand-alone, Fortran-based, program. The internet-based interface was written to generate an input file that will help with unit conversion and related issues.

\section{Description of Interface}

The web page that accepts input data for the analytical solutions was designed as a form with appropriate entry boxes for the four analytical solutions. The user enters the desired input data in the boxes for one of the solutions and submits the form for evaluation. The units for the required input data are given on the form. The user must ensure that the input values are in the correct units. Results are returned in a new window as a table. These values may be cut from the returned table and pasted into a variety of programs to plot the results if desired. The interface also allows the user to generate the header for an input file to STRMDEPL08; this header may be augmented with a pumping schedule to generate results using the standalone executable. 


\section{Example Problems and Verification of Results}

Results of the internet-based application are shown to match those from the Fortran STRMDEPL08 program. Input files and excerpts from output files for each of the four test cases are included as Appendix 1.

The first test case is for the Jenkins (1968) solution. The input data were:
Distance, $\mathrm{ft}$

500

Transmissivity, $\mathrm{ft}^{2} /$ day

1000

Storage Coefficient

0.1

Pumping Rate, gallons per minute

250

Days of Pumping

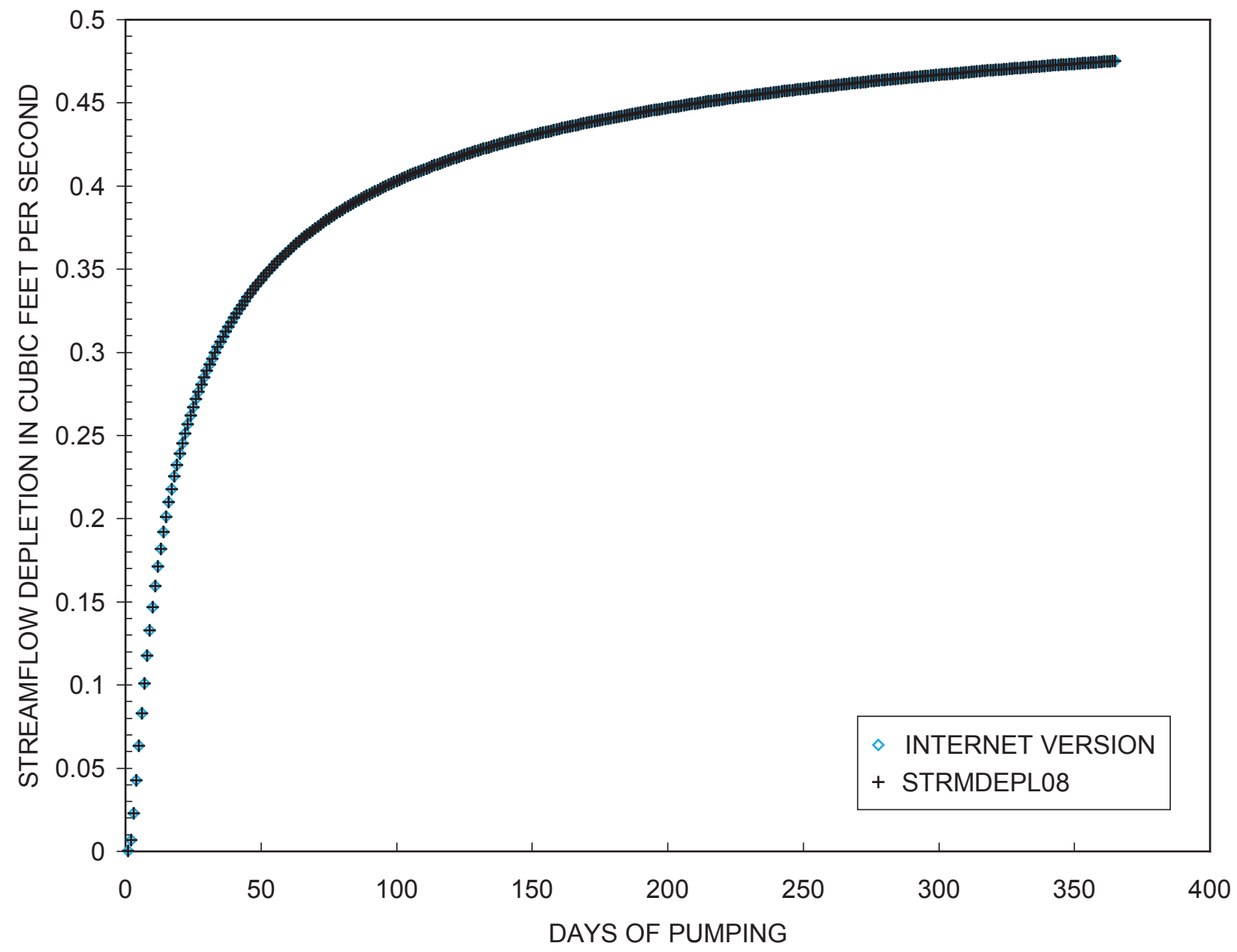

Figure 1. Comparison of results determined by the internet-based version and the Fortran version of STRMDEPL08 for the Jenkins (1968) (Glover and Balmer, 1954) analytical solution. 
The second test is for the Hantush (1965) solution.

Distance, $\mathrm{ft}$

Transmissivity, $\mathrm{ft}^{2} /$ day

Storage Coefficient

Streambed Leakance, $\mathrm{ft}$

Pumping Rate, gallons per minute

Days of Pumping
500

1000

0.1

100

250

365

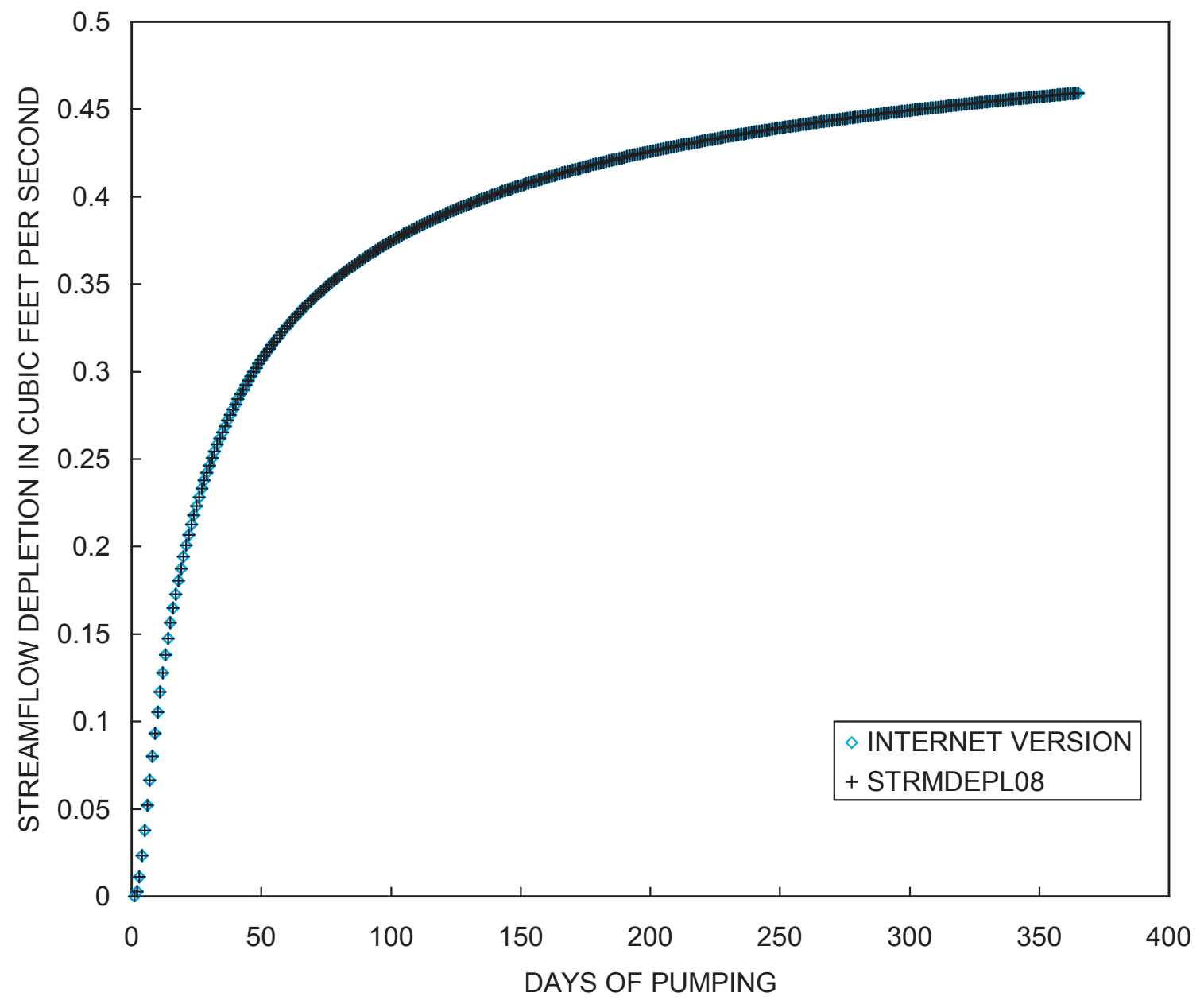

Figure 2. Comparison of results determined by the internet-based version and the Fortran version of STRMDEPL08 for the Hantush (1965) analytical solution. 
The third test is for the Hunt (1999) analytical solution.

Distance, $\mathrm{ft}$

Transmissivity, $\mathrm{ft}^{2} /$ day

Storage Coefficient

Streambed Conductance, $\mathrm{ft} /$ day

Pumping Rate, gallons per minute

Days of Pumping
500

1000

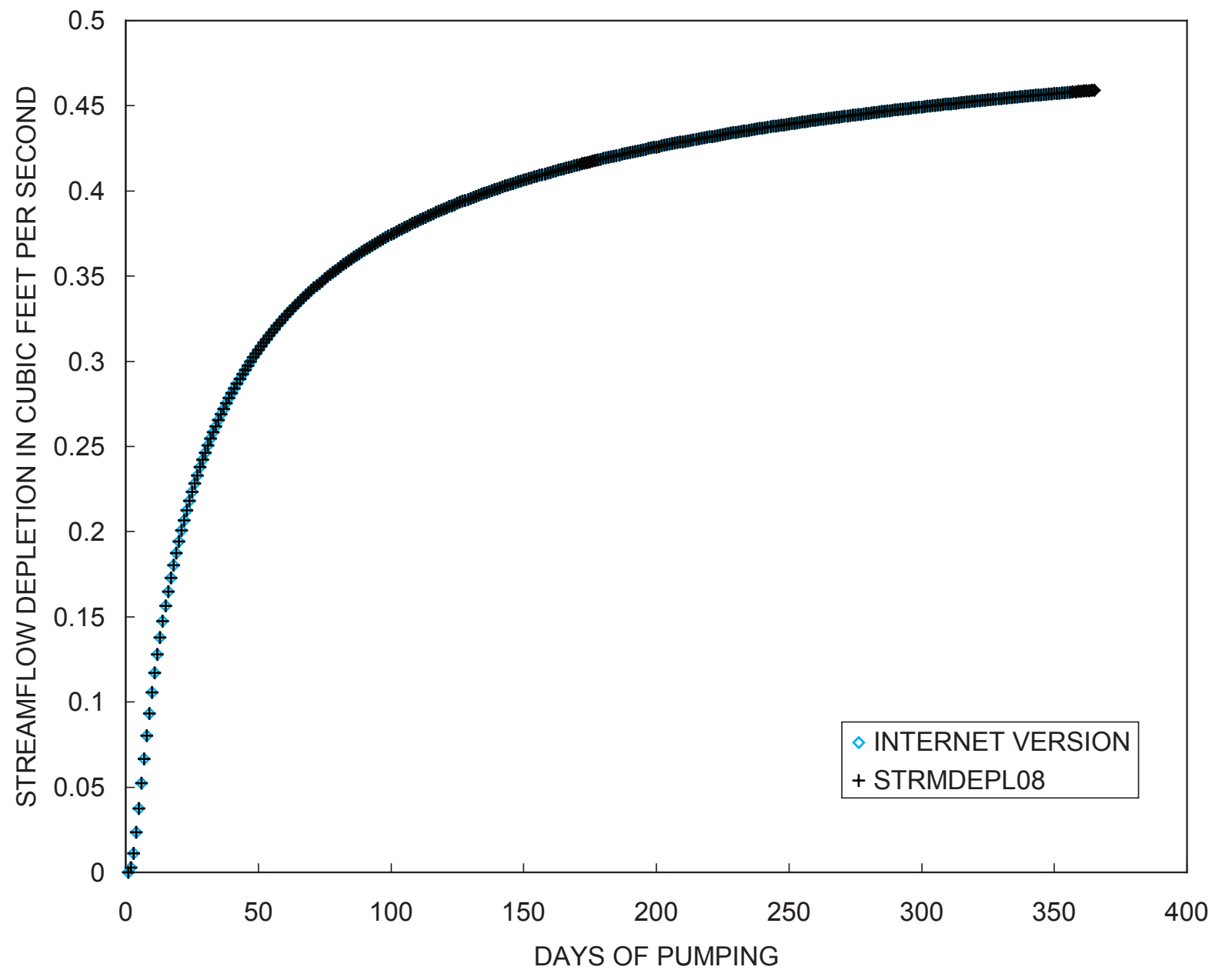

Figure 3. Comparison of results determined by the internet-based version and the Fortran version of STRMDEPL08 for the Hunt (1999) analytical solution. 
The final test is for the Hunt (2003) analytical solution

Distance, $\mathrm{ft}$

Transmissivity, $\mathrm{ft}^{2} /$ day

Storage Coefficient

Specific Yield of Aquitard

Hydraulic Conductivity of Aquitard, ft/day

Stream Width, $\mathrm{ft}$

Thickness of Aquitard, $\mathrm{ft}$

Distance from Streambed to Bottom of Aquitard, $\mathrm{ft}$

Pumping Rate, gallons per minute

Days of Pumping

500
1000
0.0001
0.1
0.1
10
20
15
250
365

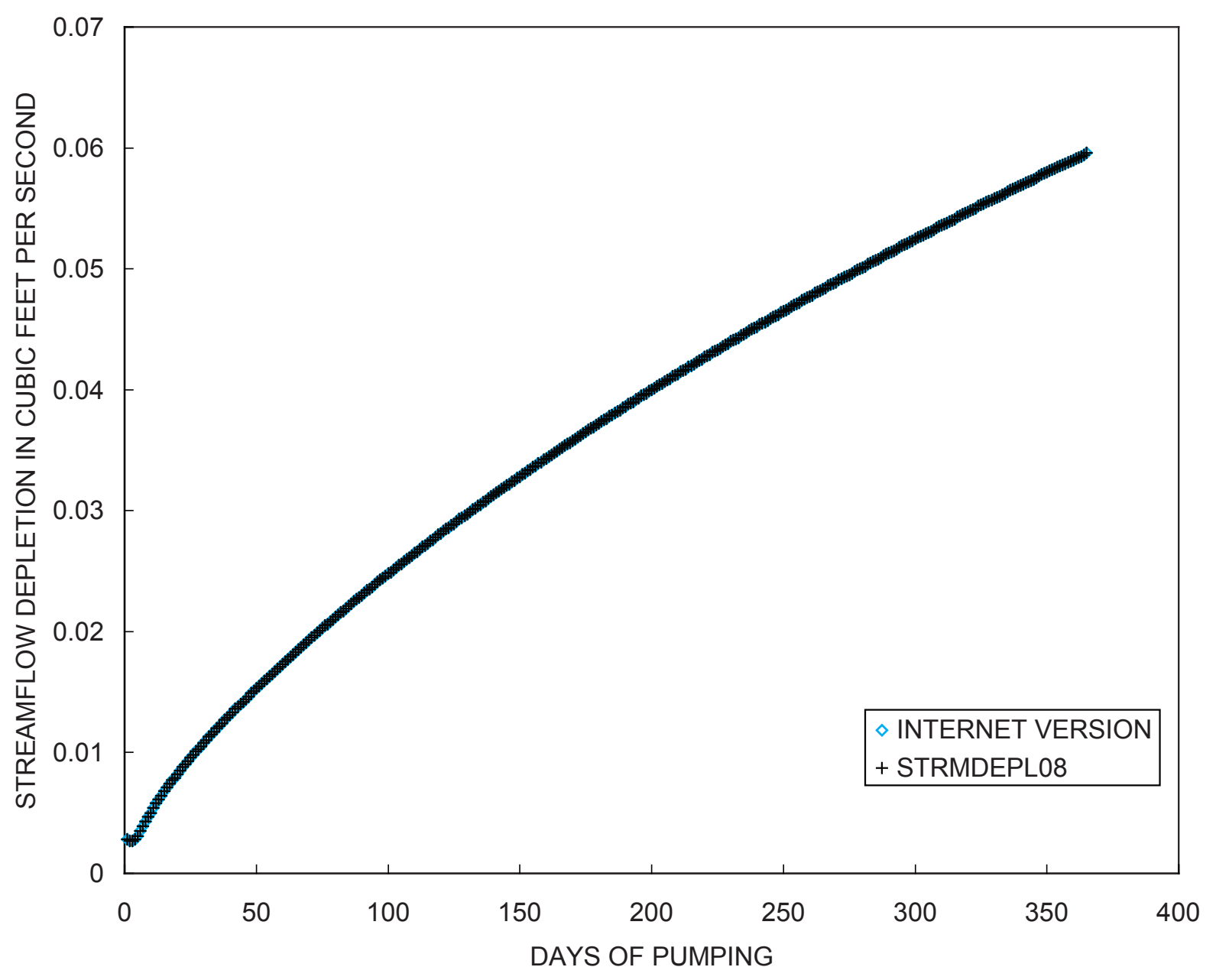

Figure 4. Comparison of results determined by the internet-based version and the Fortran version of STRMDEPL08 for the Hunt (2003) analytical solution. 


\section{Using a Spreadsheet To Develop Intermittent Pumping Input}

After the aquifer characteristics and pumping well location are listed, the STRMDEPL and STRMDEPL08 programs require two columns of input. The first column has the date in a YYYYMMDD $[\mathrm{HH}]$ format. The second column is the pumping rate in cubic feet per second. A spreadsheet can be used to help generate these input data (Figure 5).

$\begin{array}{ccccccc}\text { Date } & \text { Year } & \text { Month } & \text { Day } & \text { Pumping Rate, gpm } & \text { YMDH } & \text { Pumping rates, cfs } \\ 1 / 1 / 2010 & 2010 & 1 & 1 & 0 & 2010010100 & 0 \\ 1 / 2 / 2010 & 2010 & 1 & 2 & 0 & 2010010200 & 0 \\ 1 / 3 / 2010 & 2010 & 1 & 3 & 0 & 2010010300 & 0 \\ 1 / 4 / 2010 & 2010 & 1 & 4 & 0 & 2010010400 & 0 \\ 1 / 5 / 2010 & 2010 & 1 & 5 & 0 & 2010010500 & 0 \\ 1 / 6 / 2010 & 2010 & 1 & 6 & 0 & 2010010600 & 0 \\ 1 / 7 / 2010 & 2010 & 1 & 7 & 0 & 2010010700 & 0\end{array}$

Figure 5. Example spreadsheet that may be used to help generate intermittent pumping input information for STRMDEPL08.

The first column has the date for pumping. The user can type a starting date and then fill in remaining rows of the spreadsheet with subsequent dates for the desired simulation period. The adjacent columns are used to format the date and input the intermittent pumping for use in STRMDEPL08:

Column 2: extract the year from the date in column 1. In Microsoft Excel, the command =year(A2) can be entered into cell B2 and then filled down.

Column 3: extract the month from the date in column 1. In Microsoft Excel, the command $=$ month(A2) can be entered into cell $\mathrm{C} 2$ and then filled down.

Column 4: extract the day from the date in column 1. In Microsoft Excel, the command =day(A2) can be entered into cell D2 and then filled down.

Column 5: user input of the desired pumping rate in gallons per minute (gpm). This column can be used to input the pumping rate and intermittent schedule. The values must be converted to cubic feet per second for input to the analytical solution.
Column 6: combine the year, month, and day columns to form the date required by STRMDEPL08. In Microsoft Excel, the command $=$ CONCATENATE $(\mathrm{B} 2, \mathrm{IF}(\mathrm{C} 2<10$, CONCATENATE("0",C2),C2), IF (D2<10,CONCATENATE(“0”,,D2 ),D2),"00") can be entered into cell E2 and then filled down.

Column 7 has the intermittent pumping in cubic feet per second (cfs). The pumping rate can vary daily. It can be entered directly or the user can enter the pumping rate in gpm into column 5 and allow the spreadsheet to convert the values to $\mathrm{cfs}$ with the entry $=\mathrm{E} 2 / 448.8$ and filling down.

To generate an input file for STRMDEPL08, copy columns 6 and 7 and paste at the end of the aquifer and well information generated by the web-page interface. 


\section{Acknowledgements}

Shuangshuang Xie (Institute for Water Research, Michigan State University) worked on the conversion from Fortran to Javascript, along with contributions from Scott McPherson and Brian McPherson (Michigan State University) on the web page layout. Marie Reynolds resolved issues with USGS web-page style requirements and finalized the web version. The authors would like to thank Ralph Abele (U.S. Environmental Protection Agency), and Corinne Fitting and Kevin Neary (Connecticut Department of Environmental Protection) for their review of early versions of the interface, helpful comments, and patience with the pace of the development. This work was done in cooperation with the U.S. Environmental Protection Agency.

\section{References}

Barlow, P.M., 2000, Documentation of computer program STRMDEPL-A program to calculate streamflow depletion by wells using analytical solutions, in Zarriello, P.J., and Ries, K.G., III, A precipitation-runoff model for analysis of the effects of water withdrawals on streamflow, Ipswich River Basin, Massachusetts: U.S. Geological Survey Water-Resources Investigations Report 00-4029, p. $77-89$.

Glover, R.E., and Balmer, G.G., 1954, River depletion resulting from pumping a well near a river: Transactions, American Geophysical Union, v. 35, no. 3, p. 468-470.

Hantush, M.S., 1965, Wells near streams with semipervious beds: Journal of Geophysical Research, v. 70, no. 12, p. 2829-2838.

Hunt, Bruce, 1999, Unsteady stream depletion from ground water pumping: Ground Water, v. 37, no. 1, p. 98-102.

Hunt, Bruce, 2003, Unsteady stream depletion when pumping from semiconfined aquifer: Journal of Hydrologic Engineering, v. 8, no. 1, p. 12-19.

Jenkins, C.T., 1968, Computation of rate and volume of stream depletion by wells: U.S. Geological Survey Techniques of Water-Resources Investigations, book 4, chap. D1, 17 p.

Reeves, H.W., 2008, STRMDEPL08-An extended version of STRMDEPL with additional analytical solutions to calculate streamflow depletion by nearby pumping wells: U.S. Geological Survey Open-File Report 2008-1166, 22 p. (also available at http://pubs.water.usgs.gov/ofr20081166/.) 
Appendix 


\section{Appendix 1}

\section{Input file for Jenkins (1968) [Glover and Balmer, 1954] test:}

Jenkins test

hypothetical_well

$500,0.115740740740741,0,0,0.0,0,0,0,0,0,0.0$

$3650,0.0$

365

$2000100100 \quad 0.5570$

$2000100200 \quad 0.5570$

$2000100300 \quad 0.5570$

Repeats for 365 days

\section{Leading 60 lines of output file:}

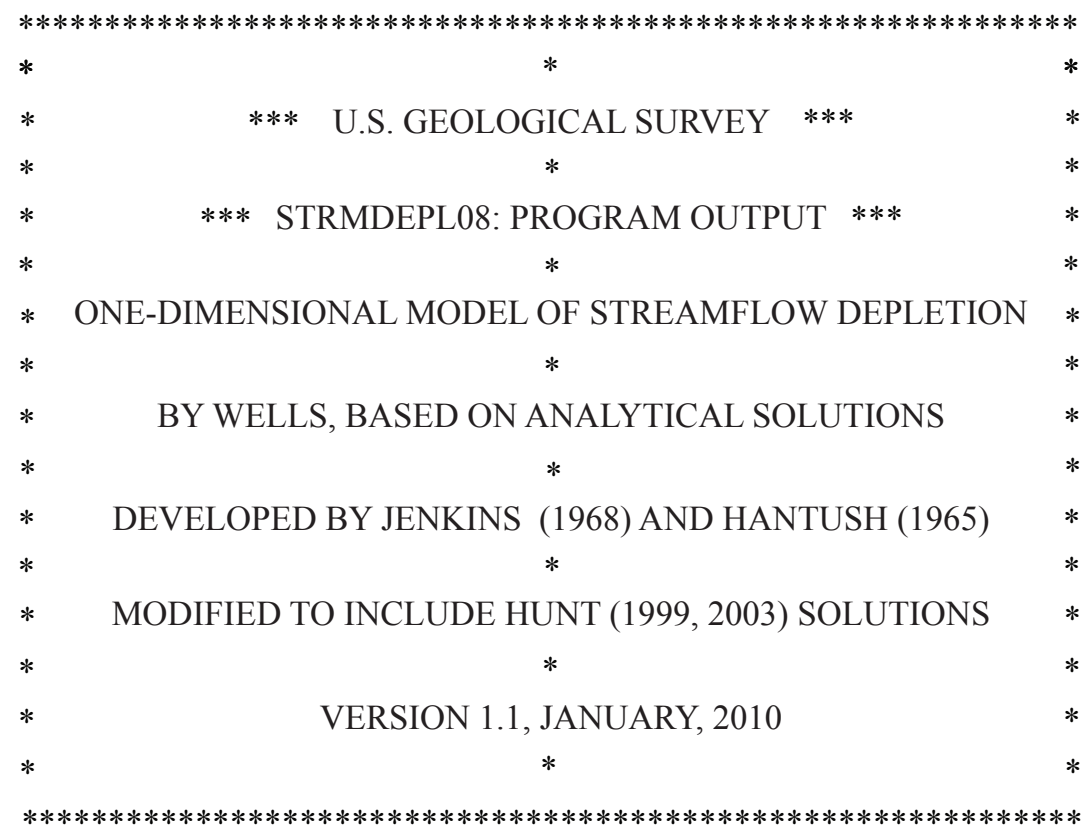

HW Reeves, USGS Michigan Water Science Center

SUMMARY OF INPUT DATA

\begin{tabular}{ll} 
WELL IDENTIFIER: & hypothetical_well \\
WELL DISTANCE TO STREAM (XWELL): & $0.500 \mathrm{D}+03$ feet \\
DIFFUSIVITY (DIFFUS): & $0.116 \mathrm{D}+00$ square feet per second \\
STREAMBANK CODE (ISOLN): & 0 (semipervious streambank absent, Jenkins 1968) \\
INITIAL TIME (INTIME): & 3650 days \\
INITIAL PUMPING RATE (QWINIT): & $0.000 \mathrm{D}+00$ cubic feet per second \\
NUMBER OF PUMPING STEPS (NPD): & 365 \\
TIME STEP FOR PUMPING (DELT): & $0.100 \mathrm{D}+01$ days \\
\hline
\end{tabular}




\section{RESULTS}

\section{STREAMFLOW DEPLETION AT BEGINNING OF ANALYSIS \\ 0.0000 cubic feet per second}

\begin{tabular}{ccc}
\multirow{2}{*}{ DAY } & PUMPING RATE & $\begin{array}{c}\text { STREAMFLOW } \\
\text { DEPLETION }\end{array}$ \\
\cline { 2 - 3 } & \multicolumn{2}{c}{ (cubic feet per second) } \\
\hline 2000100100 & 0.5570 & 0.0002 \\
2000100200 & 0.5570 & 0.0069 \\
2000100300 & 0.5570 & 0.0230 \\
2000100400 & 0.5570 & 0.0429 \\
2000100500 & 0.5570 & 0.0634 \\
2000100600 & 0.5570 & 0.0829 \\
2000100700 & 0.5570 & 0.1011 \\
2000100800 & 0.5570 & 0.1177 \\
2000100900 & 0.5570 & 0.1329 \\
2000101000 & 0.5570 & 0.1468 \\
2000101100 & 0.5570 & 0.1595 \\
\hline
\end{tabular}




\section{Input file for Hantush (1965) test:}

Hantush 1965 test hypothetical_well $500,0.115740740740741,1,100,0.0,0,0,0,0,0,0.0$

$3650,0.0$

365

$2000100100 \quad 0.5570$

$2000100200 \quad 0.5570$

$2000100300 \quad 0.5570$

Repeats for 365 days

\section{Leading 60 lines of output file:}

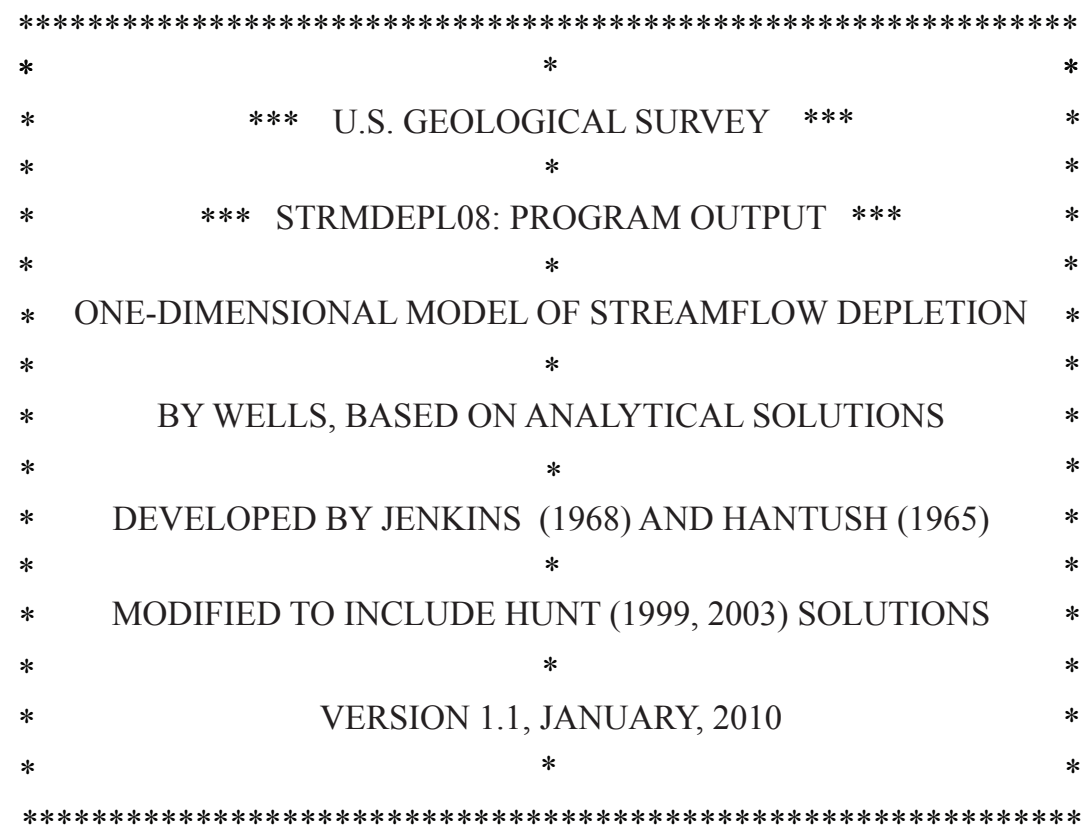

HW Reeves, USGS Michigan Water Science Center

SUMMARY OF INPUT DATA

\begin{tabular}{ll} 
WELL IDENTIFIER: & hypothetical_well \\
WELL DISTANCE TO STREAM (XWELL): & $0.500 \mathrm{D}+03$ feet \\
DIFFUSIVITY (DIFFUS): & $0.116 \mathrm{D}+00$ square feet per second \\
STREAMBANK CODE (ISOLN): & 1 (semipervious streambank simulated, Hantush, 1965)) \\
STREAMBANK LEAKANCE (SLEAK): & $0.100 \mathrm{D}+03$ feet \\
INITIAL TIME (INTIME): & 3650 days \\
INITIAL PUMPING RATE (QWINIT): & $0.000 \mathrm{D}+00$ cubic feet per second \\
NUMBER OF PUMPING STEPS (NPD): & 365 \\
TIME STEP FOR PUMPING (DELT): & $0.100 \mathrm{D}+01$ days \\
\hline
\end{tabular}


RESULTS

STREAMFLOW DEPLETION AT BEGINNING OF ANALYSIS

0.0000 cubic feet per second

\begin{tabular}{ccc}
\multirow{2}{*}{ DAY } & $\begin{array}{c}\text { PUMPING RATE } \\
\text { STREAMFLOW } \\
\text { DEPLETION }\end{array}$ \\
\cline { 2 - 3 } 2000100100 & 0.5570 & 0.0001 \\
2000100200 & 0.5570 & 0.0028 \\
2000100300 & 0.5570 & 0.0112 \\
2000100400 & 0.5570 & 0.0235 \\
2000100500 & 0.5570 & 0.0376 \\
2000100600 & 0.5570 & 0.0522 \\
2000100700 & 0.5570 & 0.0665 \\
2000100800 & 0.5570 & 0.0802 \\
2000100900 & 0.5570 & 0.0932 \\
2000101000 & 0.5570 & 0.1055 \\
\hline
\end{tabular}




\section{Input file for Hunt (1999) test:}

Hunt 1999 test

hypothetical_well

$500,0.0115740740740741,2,0.000231481481481481,0.1,0,0,0,0,0,0.0$

$3650,0.0$

365

$2000100100 \quad 0.5570$

$2000100200 \quad 0.5570$

$2000100300 \quad 0.5570$

Repeats for 365 days

\section{Leading 60 lines of output file:}

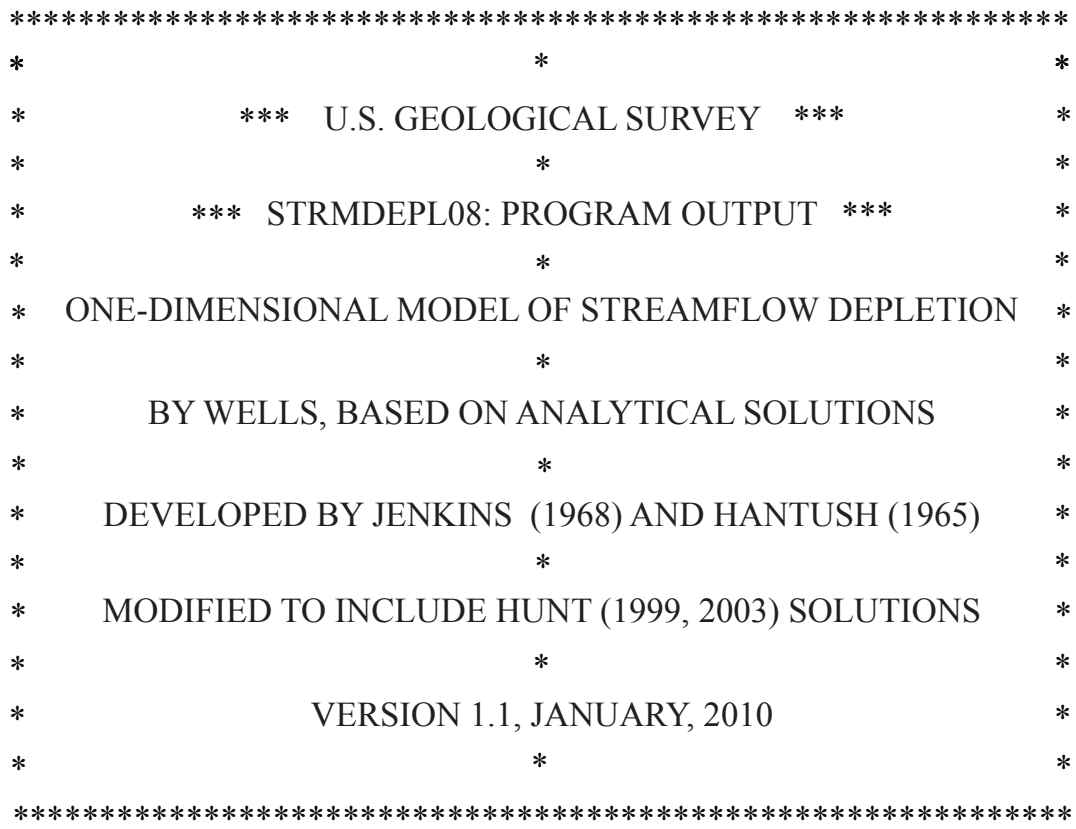

HW Reeves, USGS Michigan Water Science Center

\section{SUMMARY OF INPUT DATA}

\begin{tabular}{ll} 
WELL IDENTIFIER: & hypothetical_well \\
WELL DISTANCE TO STREAM (XWELL): & $0.500 \mathrm{D}+03$ feet \\
TRANSMISSIVITY: & $0.116 \mathrm{D}-01$ square feet per second \\
STORATIVITY & $0.100 \mathrm{D}+00$ \\
STREAMBANK CODE (ISOLN): & 2 (partially penetrating stream with resistance, Hunt 1999) \\
STREAMBED CONDUCTANCE: & $0.231 \mathrm{D}-03$ feet \\
INITIAL TIME (INTIME): & 3650 days \\
INITIAL PUMPING RATE (QWINIT): & $0.000 \mathrm{D}+00$ cubic feet per second \\
NUMBER OF PUMPING STEPS (NPD): & 365 \\
TIME STEP FOR PUMPING (DELT): & $0.100 \mathrm{D}+01$ days \\
\hline
\end{tabular}




\section{RESULTS}

\section{STREAMFLOW DEPLETION AT BEGINNING OF ANALYSIS \\ 0.0000 cubic feet per second}

\begin{tabular}{ccc}
\multirow{2}{*}{ DAY } & $\begin{array}{c}\text { PUMPING RATE } \\
\text { STREAMFLOW } \\
\end{array}$ & \multicolumn{2}{c}{$\begin{array}{c}\text { (cubic feet per second) } \\
\text { DEPLION }\end{array}$} \\
\cline { 2 - 3 } 2000100100 & 0.5570 & 0.0001 \\
2000100200 & 0.5570 & 0.0028 \\
2000100300 & 0.5570 & 0.0112 \\
2000100400 & 0.5570 & 0.0235 \\
2000100500 & 0.5570 & 0.0376 \\
2000100600 & 0.5570 & 0.0522 \\
2000100700 & 0.5570 & 0.0665 \\
2000100800 & 0.5570 & 0.0802 \\
2000100900 & 0.5570 & 0.0932 \\
\hline
\end{tabular}




\section{Input file for Hunt (2003) test:}

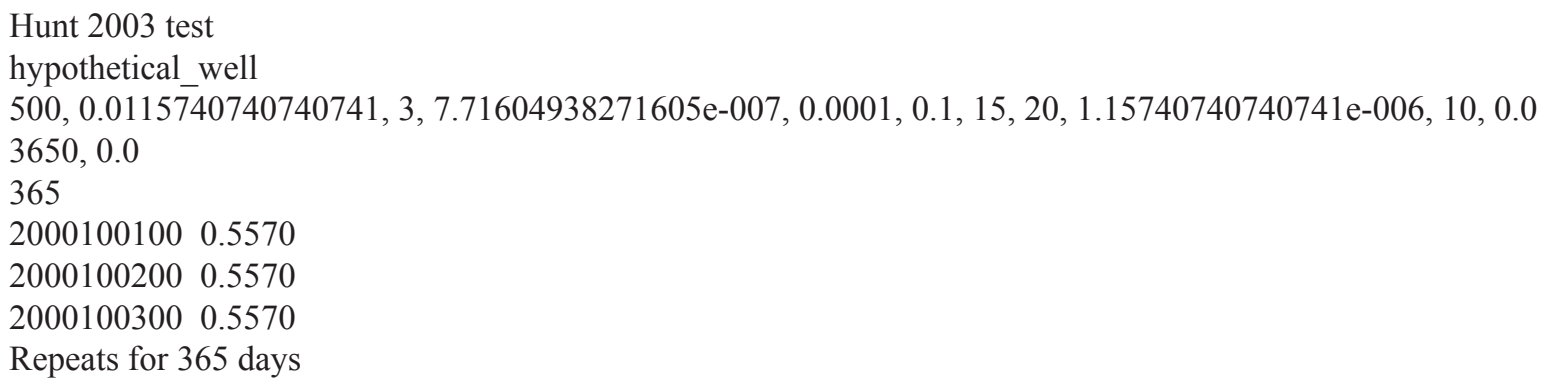

\section{Leading 60 lines of output file:}

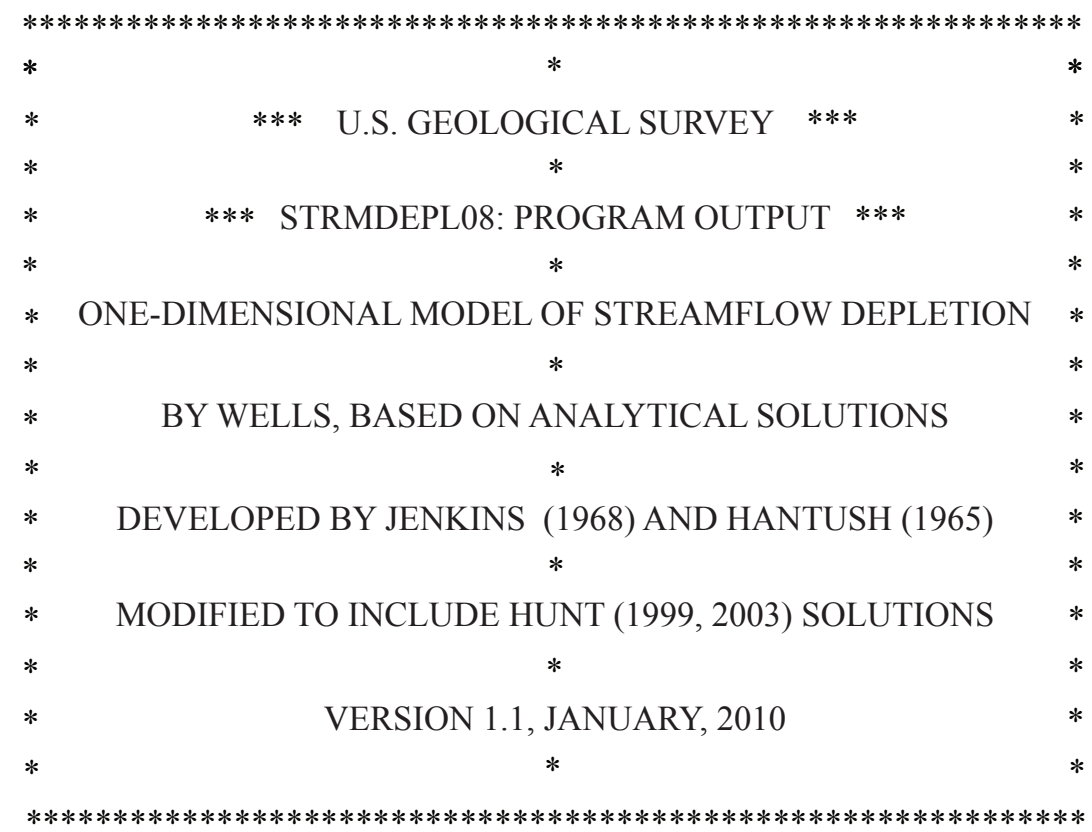

HW Reeves, USGS Michigan Water Science Center 
SUMMARY OF INPUT DATA

\begin{tabular}{ll} 
WELL IDENTIFIER: & hypothetical_well \\
WELL DISTANCE TO STREAM (XWELL): & $0.500 \mathrm{D}+03$ feet \\
TRANSMISSIVITY: & $0.116 \mathrm{D}-01$ square feet per second \\
HYDRAULIC COND. OF UPPER LAYER: & $0.116 \mathrm{D}-05$ feet per second \\
STORATIVITY & $0.100 \mathrm{D}-03$ \\
SPECIFIC YIELD OF UPPER LAYER: & $0.100 \mathrm{D}+00$ \\
STREAM WIDTH: & $0.100 \mathrm{D}+02$ feet \\
THICKNESS OF UPPER LAYER: & $0.200 \mathrm{D}+02$ feet \\
BOT. OF STREAM->TOP OF AQUIFER: & $0.150 \mathrm{D}+02$ feet \\
STREAMBANK CODE (ISOLN): & 3 (stream in overlying aquitard simulated, Hunt 2003) \\
STREAMBANK CONDUCTANCE: & $0.772 \mathrm{D}-06$ feet per second \\
INITIAL TIME (INTIME): & 3650 days \\
INITIAL PUMPING RATE (QWINIT): & $0.000 \mathrm{D}+00$ cubic feet per second \\
NUMBER OF PUMPING STEPS (NPD): & 365 \\
TIME STEP FOR PUMPING (DELT): & $0.100 \mathrm{D}+01$ days \\
\hline
\end{tabular}

RESULTS

STREAMFLOW DEPLETION AT BEGINNING OF ANALYSIS

0.0000 cubic feet per second

\begin{tabular}{ccc}
\multirow{2}{*}{ DAY } & PUMPING RATE & $\begin{array}{c}\text { STREAMFLOW } \\
\text { DEPLETION }\end{array}$ \\
\cline { 2 - 3 } & \multicolumn{2}{c}{ (cubic feet per second) } \\
\hline 2000100100 & 0.5570 & 0.0028 \\
2000100200 & 0.5570 & 0.0027 \\
2000100300 & 0.5570 & 0.0027 \\
2000100400 & 0.5570 & 0.0028 \\
2000100500 & 0.5570 & 0.0031 \\
2000100600 & 0.5570 & 0.0035 \\
2000100700 & 0.5570 & 0.0039 \\
2000100800 & 0.5570 & 0.0043 \\
2000100900 & 0.5570 & 0.0047 \\
2000101000 & 0.5570 & 0.0050 \\
2000101100 & 0.5570 & 0.0054 \\
2000101200 & 0.5570 & 0.0058 \\
2000101300 & 0.5570 & 0.0061 \\
2000101400 & 0.5570 & 0.0064 \\
\hline
\end{tabular}






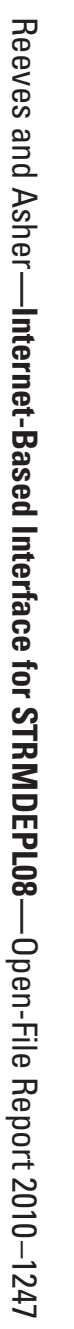

8 Printed on recycled paper 